A Thumbnail Sketch of Theatre Nursing 


\title{
A Thumbnail Sketch of Theatre Nursing
}

\author{
JENNIFER ANN MORRIS, SRN, SCM
}

Illustrations by

JANET NUNN

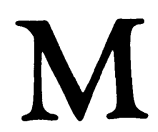


Text $\odot$ Jennifer Ann Morris 1983

Illustrations (C) Janet Nunn 1983

Softcover reprint of the hardcover 1st edition 1983 978-0-333-35769-9

All rights reserved. No part of this publication may be reproduced or transmitted, in any form or by any means, without permission.

First published 1983 by

THE MACMILLAN PRESS LTD

London and Basingstoke

Companies and representatives throughout the world

Typeset in Rockwell by Repro-type, London N13, England.

ISBN 978-0-333-35770-5 ISBN 978-1-349-17237-5 (eBook) DOI $10.1007 / 978-1-349-17237-5$ 


\section{CONTENTS}

Introduction viii

Acknowledgements ix

1. On First Entering Theatre 2

Changing clothes 3

Tour of theatre suite 5

Policies 6

2. Reception Area 7

3. Anaesthetic Room 8

Nurse duties: Checking 9

Equipment 10

Patient in anaesthetic room 16

Patient anaesthesia $\quad 18$

Drugs used in anaesthesia 20

Regional anaesthesia 23

Local anaesthesia 24

Cardiac arrest 25

4. Preparation of Theatre 26

Circulating nurse duties 26

Scrub nurse duties 28 


\section{CONTENTS}

5. The Operation 39

Scrub nurse duties $\quad 40$

Circulating nurse duties $\quad 46$

Cardiac arrest 50

6. Recovery Room 52

Preparation 52

Patient in recovery room 53

Respiratory or cardiac arrest 56

7. Theatre Sterile Supply Unit 57

Instruments $\quad 59$

Sutures 62/63

8. Conclusion 65

Glossary $\quad 66$

Appendix: Outline of the Recommended Syllabus $\quad 67$

Useful Addresses $\quad 69$

$\begin{array}{ll}\text { Index } & 72\end{array}$ 


\section{INTRODUCTION}

This book is intended primarily for student nurses entering the operating theatre for the first time. In unfamiliar surroundings, with people unrecognisably hidden behind caps and masks, instant indignation if the wrong thing is touched and none of the familiar ward routines, the new staff member is every bit as anxious as the patient!

This is not intended as a definitive textbook but rather as a good humoured guide for the student nurse during the initial phase of learning theatre routine.

For the text to flow smoothly, 'student nurse' also refers to trainee operating department assistant (ODA) and auxiliaries. Also for reasons of flow, not prejudice, the nurse is usually refered to as 'she', and the doctor as 'he'. The duties of trained nurses applies equally to trained ODAs.

The book is designed to fit into the theatre uniform and can be used as a reference easily available when the nurse feels too nervous to ask questions in a busy theatre suite. For more details and for specialist procedures the nurse should avail herself of further textbooks on the theatre bookshelf.

This book is written with a number of countries in mind, including Canada, the USA and the 'developing' ones. The descriptions of scrubbing up, gowning and gloving are detailed as the student nurse may need to refer to them when practising at home. Lists of instruments have been deliberately excluded as no two surgeons use the same, finance dictates what is purchased and names vary between countries.

We are as one in the common cause of improving patient care.

Kidlington, 1983 


\section{ACKNOWLEDGEMENTS}

I should like to thank Miss Josephine Daly and Miss Ann Adams of The Royal Free Hospital London for their help and inspiration, and Janet Nunn whose illustrations clarify and add humour to the text.

I am grateful to my mother, Mrs Ida Morris, for painstaking typing and to the National Association of Theatre Nurses for the aims and objectives of theatre experience and the recommended syllabus. 